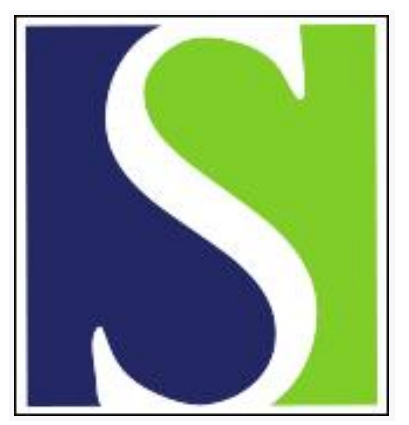

Scand J Work Environ Health 1991;17(6):386-391

https://doi.org/10.5271/sjweh.1689

Issue date: Dec 1991

Importance of accurate employment histories of patients admitted to units of internal medicine.

by Gennart JP, Hoet P, Lison D, Lauwerys R, Coche E, Lambert M

Affiliation: Industrial Toxicology and Occupational Medicine Unit, School of Medicine, Catholic University of Louvain, Brussels, Belgium.

This article in PubMed: www.ncbi.nlm.nih.gov/pubmed/1788531 


\title{
Importance of accurate employment histories of patients admitted to units of internal medicine
}

\author{
by Jean-Philippe Gennart, MD, ${ }^{1}$ Perrine Hoet, MD, ${ }^{1}$ Dominique Lison, $M D,{ }^{1}$ \\ Robert Lauwerys, MD, ${ }^{1}$ Edgard Coche, MD, ${ }^{2}$ Michel Lambert, $M D^{2}$
}

\begin{abstract}
GENNART JP, HOET P, LISON D, LAUWERYS R, COCHE E, LAMBERT M. Importance of accurate employment histories of patients admitted to units of internal medicine. Scand $J$ Work Environ Health 1991;17:386-91. A study was undertaken to assess the importance of systematically recording occupational histories of patients admitted to an internal medicine unit of a university hospital. Detailed information on current and past employment was obtained with questionnaires and in personal interviews from 200 inpatients over a 12 -month period. Twenty-one patients $(10.5 \%)$ were considered to have a "primary illness" (condition causing hospital admission) probably $(4.5 \%)$ or possibly $(6 \%)$ related to their current or previous occupation. From the 786 primary and secondary illnesses and medical antecedents diagnosed for the 200 patients examined, 70 illnesses of 55 patients were considered probably or possibly related to current or previous occupation. This pilot study emphasizes the need for accurate occupational records for patients in an internal medicine ward. This task is best performed by an appropriately trained occupational physician.
\end{abstract}

Key terms: medical history, occupational disease.

Despite all the sophisticated techniques available to detect functional and morphological organ disturbances, accurate records of a patient's medical history remain of paramount importance. An accurate history can yield essential information with which to formulate possible diagnoses, suggest complementary investigations, adapt the treatment, or assess the prognosis of the illness. The medical history is also the most valuable tool in identifying those environmental factors which cause or aggravate certain pathological conditions. However, the general practitioner and the internist usually limit their questioning to dietary, smoking, and drinking habits and drug consumption. The occupational history is not frequently assessed in detail because it is difficult to perform correctly, is timeconsuming, and is considered rarely productive. An evaluation of medical charts by Sokas et al (1) revealed that only half of the charts recorded employment status. It is not surprising that over $80 \%$ of the occupational diseases identified in two occupational medicine clinics in the United States were not correctly diagnosed by the primary physicians (2).

But even when a job history is provided by the patient, it is often difficult to ascertain occupational risks for the following reasons: (i) occupational environments are complex and rapidly changing and physi-

\footnotetext{
1 Industrial Toxicology and Occupational Medicine Unit, School of Medicine, Catholic University of Louvain, Brussels, Belgium.

2 Department of Internal Medicine, School of Medicine, Catholic University of Louvain, Brussels, Belgium.
}

Reprint requests to: Dr J-P Gennart, Industrial Toxicology and Occupational Medicine Unit, Catholic University of Louvain, 30.54. Clos Chapelle-aux-Champs, B-1200 Brussels, Belgium. cians who are unfamiliar with modern industrial activities cannot always identify the occupational risks in a patient's job; (ii) patients cannot always provide the names of the chemical compounds present at their workplace; (iii) industrial confidentiality may prevent the disclosure of names or formulas of industrial chemical preparations; (iv) the long latency period between the onset of exposure and the symptoms of some diseases (eg, cancer) leads to forgetfulness about past exposure; and (v) the search for an occupational factor is often not considered if another etiologic agent has been identified (eg, tobacco consumption for a patient with lung cancer).

The present pilot study was undertaken to assess the importance of systematically recording occupational histories of patients admitted to an internal medicine unit of a Belgian university hospital. The objective was not to determine the pattern of occupational diseases which may be diagnosed in Belgian hospitals, but to assess whether a detailed occupational record is justified in the medical work-up of hospitalized patients. Although the design of such a study cannot totally exclude the possible influence of observer biases, effort was made to reduce it as much as possible by having the assessment performed independently by four occupational physicians. The results of this preliminary study provide a clear indication of the importance of occupational risk factors in the pathogenesis of diseases diagnosed in general and internal medicine.

\section{Subjects and methods}

\section{Population and hospital characteristics}

The study population was a random sample of all the patients who were admitted to a general internal medi- 
cine unit in a 12-month period and who fulfilled the following criteria: (i) held paid employment for at least one year in a lifetime and (ii) able to answer a questionnaire and be interviewed for $1 \mathrm{~h}$. Fifty percent of the patients lived in the city of Brussels (1 million inhabitants). The remaining $50 \%$ resided in the Frenchspeaking area of Belgium ( 3.5 million inhabitants). The hospital had no selection criteria at admission. It acted as a general hospital for the urban population of Brussels and as a referral hospital for the French-speaking area of the country. No Belgian hospital has an inpatient occupational medicine unit.

A sample of 224 patients was initially selected, representing $10 \%$ of the patients hospitalized in the internal medicine unit during the study period. Nineteen people were considered uncooperative and five patients who had filled out the forms were discharged before the interview could take place. Two hundred patients ( 157 men and 43 women) were included in the final study. Their ages ranged from 20 to 82 (mean 51.8, SD 14.6) years. One hundred and thirty-three were still occupationally active; 59 were retired, and eight were unemployed at the time of the study. The ratio of blue-collar to white-collar workers was 85:115. The characteristics of the study population (age and cause and duration of hospitalization) were not markedly different from those of the total population admitted to the internal medicine unit during the same period. The proportion of women was lower in the study population ( 22 versus $45 \%$ ) since $56 \%$ of the hospitalized women had never held paid employment and were not selected for the study.

\section{Occupational history}

At admission, each patient in the study population was given a detailed questionnaire adapted from that of Rosenstock et al (3). The form was designed to collect information on (i) all occupational activities, (ii) exposure to chemical, physical, or infectious agents at work and otherwise, (iii) use of personal protective equipment, (iv) personal hygiene practices, (v) second job, and (vi) hobbies. Two or three days later, personal interviews allowed the patient's answers to be explored in depth. The interviews were conducted by three occupational physicians. In several cases, additional information was requested from the employer or the plant physician. After the patients' discharge from the hospital, their medical files were examined and the following data were extracted: (i) diagnosis of the illness which motivated the admission (primary illness), (ii) other diseases identified during the medical work-up (secondary illnesses), and (iii) medical antecedents (ie, diseases which occurred in the past).

Congenital and perinatal diseases, pregnancy, and accidents were not considered in the study. Occupations and diseases were coded according to the classifications of the International Labour Office (4) and the World Health Organization (5). The assessment of a relationship between diseases and occupations was based on data from the literature (ie, reports of an increased relative risk of specific illnesses in some occupations or following exposure to some chemicals), but it also took into account the intensity and the duration of exposure, the latency period from onset of exposure to evidence of disease, and the possible role of other exogenous factors (smoking, alcohol, hobbies, etc).

Each current or past illness was assessed as probably related, possibly related, or not related to occupational factors. The criteria for the first category (probably related) were (i) the existence of a well-established association between job and disease and (ii) knowledge of an exposure of sufficient intensity to cause the disease (eg, pneumoconiosis in a coal worker). In the second category (possibly related), the criteria were (i) the existence of epidemiologic studies or case reports suggesting a possible association (eg, liver cirrhosis following long-term exposure to solvent mixtures) and (ii) the existence of a definite association between exposure and disease, the exposure intensity however being considered low (eg, asbestosis in a worker sawing asbestoscement products intermittently). The final assessment was performed independently by four occupational physicians. In divergent cases the decision was made jointly by the team.

\section{Results}

Twenty-one patients $(10.5 \%)$ were considered to have a primary illness which was probably related $(\mathrm{N}=9)$ or possibly related $(\mathrm{N}=12)$ to their current or previous occupations (table 1).

From the 786 primary and secondary illnesses and medical antecedents diagnosed for the 200 patients examined, 70 illnesses were considered probably related or possibly related to current or previous occupations. Therefore 55 of the 200 inpatients had illnesses resulting from employment. Table 2 presents the nosological distribution of these work-related diseases. Respiratory tract impairment represented the greatest proportion ( $25.7 \%$ ) of the 70 diseases considered probably related or possibly related to occupation. Musculoskeletal diseases were the second most frequent work-related impairments.

Seventy-three infectious diseases were identified (7 still active and 66 recorded in the medical history). Fifteen percent of these diseases were related to the patient's occupational activities. There were eight cases of cardiovascular disease caused or aggravated by occupational activities (one diagnosis of right heart failure secondary to silicosis, four cases of angina pectoris occurring in patients exposed to carbon monoxide, and three cases of lower-limb varices in patients whose jobs required long periods of standing. Six $(12 \%)$ of the 50 neoplastic diseases were considered possibly related to previous occupational activities.

Table 3 presents the distribution of patients with work-related illnesses (primary + secondary illnesses 
Table 1. Patients whose primary illness was probably or possibly related to their occupational activities. (ICD $=\mid$ nternational Classification of Diseases, ILO $=$ International Labour Office)

\begin{tabular}{|c|c|c|c|c|c|c|}
\hline $\begin{array}{l}\text { Case } \\
\text { number }\end{array}$ & Disease & $\begin{array}{l}I C D \\
\text { code }\end{array}$ & Occupational hazard & Occupation & $\begin{array}{l}\text { ILO } \\
\text { code }\end{array}$ & $\begin{array}{l}\text { Refer- } \\
\text { ences }\end{array}$ \\
\hline \multicolumn{7}{|c|}{ Probable link between occupation and primary illness } \\
\hline 22 & $\begin{array}{l}\text { Coal workers's pneumo- } \\
\text { coniosis }\end{array}$ & 5000 & Silica and coal dust & Coal mine engineer & 027 & 6 \\
\hline 35 & Asthmatic bronchitis & 4939 & $\begin{array}{l}\text { Vegetable and animal } \\
\text { dust }\end{array}$ & $\begin{array}{l}\text { Furniture upholsterer } \\
\text { (handling of wool, } \\
\text { feather, straw) }\end{array}$ & 796 & 6 \\
\hline 41 & $\begin{array}{l}\text { Chronic obstructive } \\
\text { pulmonary disease }\end{array}$ & 4912 & $\begin{array}{l}\text { Silica and coal dust, } \\
\text { nitrous oxide }\end{array}$ & Miner & 711 & 7,8 \\
\hline 64 & Brucellosis & 0239 & Brucella & Farmer & 611 & 9 \\
\hline 66 & Arthritis (staphylococcus) & 0411 & $\begin{array}{l}\text { Staphylococcus } \\
\text { (skin infection) }\end{array}$ & Farmer & 611 & 10,11 \\
\hline 100 & Cor pulmonale & 4168 & Silica and coal dust & Coal mine technician & 038 & 6 \\
\hline 114 & Malaria & 0841 & Plasmodium vivax & $\begin{array}{l}\text { TV viewman (travel } \\
\text { to Ethiopia) }\end{array}$ & 163 & 12 \\
\hline 158 & $\begin{array}{l}\text { Acute upper respiratory } \\
\text { tract inflammation }\end{array}$ & 4658 & Formaldehyde & $\begin{array}{l}\text { Operator (pharmaceutical } \\
\text { industry) regularly exposed } \\
\text { to formaldehyde }\end{array}$ & 749 & 13 \\
\hline 171 & Lumbago & 7242 & Lifting & Warehouse worker & 971 & $14-16$ \\
\hline \multicolumn{7}{|c|}{ Possible link between occupation and primary illness } \\
\hline 3 & Coronary heart disease & 4130 & Carbon monoxide & Motor vehicle mechanic & 843 & $17-22$ \\
\hline 11 & Liver cirrhosis & 5715 & Solvents & Printer & 921 & 23,24 \\
\hline 27 & Malignant hystiocytosis & 2023 & $\begin{array}{l}\text { Pesticides (?), } \\
\text { viruses (?) }\end{array}$ & Farmer & 611 & $25-32$ \\
\hline 34 & $\begin{array}{l}\text { Emphysema, broncho- } \\
\text { pneumonia }\end{array}$ & $\begin{array}{l}5064 \\
4850\end{array}$ & Solvents (aerosol) & $\begin{array}{l}\text { Production and demon- } \\
\text { stration of aerosols }\end{array}$ & 211 & $33-35$ \\
\hline 105 & $\begin{array}{l}\text { Chronic obstructive } \\
\text { pulmonary disease }\end{array}$ & 4912 & Cold, dusts & Bricklayer & 951 & 36,37 \\
\hline 120 & $\begin{array}{l}\text { Psychophysiological } \\
\text { disorder }\end{array}$ & 3060 & Solvents & $\begin{array}{l}\text { Electrician (degreasing } \\
\text { tank in the workplace) }\end{array}$ & 855 & 38,39 \\
\hline 123 & Bladder cancer & 1889 & Aromatic amines & Offset printer & 922 & $40-42$ \\
\hline 140 & Lumbar discopathy & 7221 & Lifting + vibrations & Farmer & 611 & 43 \\
\hline 169 & Pulmonary fibrosis & 4959 & Asbestos & Cement kiln worker & 742 & 6 \\
\hline 176 & Hodgkin's disease & 2015 & $\begin{array}{l}\text { Pesticides (?), } \\
\text { viruses (?) }\end{array}$ & Farmer & 611 & $\begin{array}{l}25,27 \\
41,44\end{array}$ \\
\hline 193 & $\begin{array}{l}\text { Malignant neoplasm } \\
\text { of the pleura }\end{array}$ & 1639 & Asbestos & $\begin{array}{l}\text { Roofer (sawing asbestos- } \\
\text { cement products) }\end{array}$ & 953 & 6 \\
\hline 198 & $\begin{array}{l}\text { Hyperleucocytosis } \\
\text { isolated }\end{array}$ & 2888 & Benzene & Printing house mechanic & 839 & $45-47$ \\
\hline
\end{tabular}

and medical antecedents) in the various occupational groups. It is interesting to note that all of the agricultural workers $(\mathrm{N}=6)$ had work-related illnesses.

Table 4 lists the physical, chemical, and biological agents which have been estimated to be probably or possibly responsible for the diagnosed occupational diseases.

\section{Discussion}

Before it can be concluded that a patient's illness has been caused or aggravated or accelerated by his or her current or past occupational activities, it is necessary that previous studies have reported the existence of an association between the illness and occupational risk factors and also that the circumstances of the patient's occupational exposure (intensity, duration) are compatible with a cause-effect relationship. In practice, for the various reasons already discussed (see the Introduction), the assessment of the fulfillment of both criteria is difficult. Furthermore, this assessment may also be influenced by the medical context in which it is performed (general practice, work compensation) and the relationship between the patient and the physician (family physician, insurance company physician, etc). These possible biases did not influence the results of this study, which was performed independently of any socioeconomic constraint. Despite these shortcomings, several tentative conclusions can be drawn from the study, whose validity should be assessed by a broader epidemiologic study involving several internal medicine clinics located in various industrial, urban, and rural areas.

One must, however, recognize that, in this study, most of the associations suggested between occupational exposures and diseases involved some subjec- 
Table 2. Primary and secondary illnesses and medical antecedents probably or possibly related to occupation.

\begin{tabular}{|c|c|c|c|c|c|c|c|}
\hline \multirow{2}{*}{ IlIness } & \multirow{2}{*}{$\begin{array}{c}\text { Total } \\
\text { number of } \\
\text { illnesses }\end{array}$} & \multicolumn{2}{|c|}{$\begin{array}{l}\text { Probably } \\
\text { responsible }\end{array}$} & \multicolumn{2}{|c|}{$\begin{array}{l}\text { Possibly } \\
\text { responsible }\end{array}$} & \multicolumn{2}{|c|}{ Total } \\
\hline & & $\mathbf{N}$ & $\%$ & $\mathbf{N}$ & $\%$ & $\mathbf{N}$ & $\%$ \\
\hline Infectious and parasitic diseases & 73 & 6 & 8.2 & 5 & 6.8 & 11 & 15.1 \\
\hline Neoplasms & 50 & 2 & 4 & 4 & 8 & 6 & 12 \\
\hline Endocrine, metabolic and immunologic disorders & 59 & - & 0 & 2 & 3.4 & 2 & 3.4 \\
\hline Diseases of the blood and blood forming organs & 9 & - & 0 & 1 & $11.1^{\prime}$ & 1 & 11.1 \\
\hline Mental disorders & 43 & - & 0 & 1 & 2 & 1 & 2 \\
\hline Diseases of the nervous system and sense organs & 31 & 一 & 0 & - & 0 & - & 0 \\
\hline Diseases of the circulatory system & 156 & 1 & 0.6 & 7 & 4.5 & 8 & 5.1 \\
\hline Diseases of the respiratory system & 67 & 11 & 16.4 & 7 & 10.4 & 18 & 26.9 \\
\hline Diseases of the digestive system & 165 & - & 0 & 3 & 1.8 & 3 & 1.8 \\
\hline Diseases of the genitourinary system & 60 & - & 0 & 1 & 1.6 & 1 & 1.6 \\
\hline Diseases of the skin and subcutaneous tissue & 12 & 2 & 16.7 & - & - & 2 & 16.7 \\
\hline $\begin{array}{l}\text { Diseases of the musculoskeletal system and } \\
\text { the connective tissue }\end{array}$ & 38 & 5 & 13.2 & 8 & 21 & 13 & 34.2 \\
\hline Poisonings & 14 & 3 & 21.4 & - & - & 3 & 21.4 \\
\hline Symptoms, signs and ill-defined conditions & 9 & - & - & 1 & 11 & 1 & 11 \\
\hline Total & 786 & 30 & 3.8 & 40 & 5 & 70 & 8.9 \\
\hline
\end{tabular}

Table 3. Proportion of patients with illnesses (primary + secondary + antecedents) probably or possibly related to occupations in various occupational groups. ILO = International Labour Office)

\begin{tabular}{|c|c|c|c|}
\hline \multirow[t]{2}{*}{ Occupational group } & \multirow{2}{*}{$\begin{array}{l}\text { Total } \\
\text { number of } \\
\text { patients }\end{array}$} & \multicolumn{2}{|c|}{$\begin{array}{c}\text { Patients with } \\
\text { work-related } \\
\text { disorders }\end{array}$} \\
\hline & & $\mathbf{N}$ & $\%$ \\
\hline $\begin{array}{l}\text { Professional, technical and } \\
\text { related workers (ILO } 0,1)\end{array}$ & 49 & 10 & 20 \\
\hline $\begin{array}{l}\text { Administrative and managerial } \\
\text { workers (ILO 2) }\end{array}$ & 13 & 2 & 15 \\
\hline $\begin{array}{l}\text { Chemical and related workers } \\
\text { (ILO 3) }\end{array}$ & 40 & 1 & 2.5 \\
\hline Sales workers (ILO 4) & 13 & 2 & 15.5 \\
\hline Service workers (ILO 5) & 13 & 3 & 23 \\
\hline $\begin{array}{l}\text { Agricultural, animal husbandry } \\
\text { and forestry workers, fisher- } \\
\text { men and hunters (ILO 6) }\end{array}$ & 6 & 6 & 100 \\
\hline $\begin{array}{l}\text { Production and related workers, } \\
\text { transport equipment operators } \\
\text { and laborers (ILO } 7-9 \text { ) }\end{array}$ & 66 & 27 & 41 \\
\hline
\end{tabular}

a Code of the International Standard Classification of Occupations in parentheses.

tivity since they were based on the interpretation of a questionnaire and an interview. They could not always be strengthened by objective data (eg, quantitative assessment of past exposure by environmental and/or biological data). Furthermore some reported associations are still the subject of controversy, such as the relationship between the development of coronary artery disease and long-term exposure to carbon monoxide (48).
Table 4. Chemical, physical, and biological agents probably or possibly responsible for the work-related illnesses (primary + secondary + antecedents).

\begin{tabular}{|c|c|c|c|}
\hline & $\begin{array}{c}\text { Probably } \\
\text { respon- } \\
\text { sible }\end{array}$ & $\begin{array}{l}\text { Possibly } \\
\text { respon- } \\
\text { sible }\end{array}$ & Total \\
\hline \multicolumn{4}{|l|}{ Chemical agents } \\
\hline $\begin{array}{l}\text { Carbon monoxide } \\
\text { Silica (associated or }\end{array}$ & 2 & 3 & 5 \\
\hline not with coal dust) & 6 & 1 & $\begin{array}{l}7 \\
4\end{array}$ \\
\hline $\begin{array}{l}\text { Asbestos } \\
\text { Other dusts }\end{array}$ & $\begin{array}{l}2 \\
1\end{array}$ & $\begin{array}{l}2 \\
2\end{array}$ & $\begin{array}{l}4 \\
3\end{array}$ \\
\hline Lead & - & 2 & 2 \\
\hline Solvents & 1 & 5 & $\overline{6}$ \\
\hline Others & 4 & 7 & 11 \\
\hline Total & 16 & 22 & $38(54 \%)$ \\
\hline \multicolumn{4}{|l|}{ Physical agents } \\
\hline Lifting and posture & 4 & 10 & 14 \\
\hline Vibration & 1 & 2 & 3 \\
\hline Ultraviolet rays & 2 & - & 2 \\
\hline Cold & 1 & 2 & \\
\hline Total & 8 & 13 & $21(30 \%)$ \\
\hline \multicolumn{4}{|l|}{ Biological agents } \\
\hline $\begin{array}{l}\text { Hepatitis B virus } \\
\text { Other }\end{array}$ & $\begin{array}{l}2 \\
4\end{array}$ & $\begin{array}{l}2 \\
3\end{array}$ & $\begin{array}{l}4 \\
7\end{array}$ \\
\hline Total & 6 & 5 & $11(16 \%)$ \\
\hline Total & 30 & 40 & 70 \\
\hline
\end{tabular}

Respiratory tract impairments were the most frequent work-related diseases. This finding confirms that the lung represents the main target organ of many inhaled industrial pollutants. The finding is in agreement both with the observations of Cullen \& Cherniack in the United States (2) and statistics of the Belgian Work Compensation Fund (49). In 1987, $30 \%$ of the claims received by the Belgian Fund were related to occupational lung diseases. In the present study, the propor- 
tion of work-related infectious diseases ( 10 of the total 70 ) was higher than that ( $4 \%$ ) found among the compensation claims introduced to the Belgian Work Compensation Fund in 1987 (49), even though compensation claims for most of the diagnosed infectious diseases can be directly submitted for work compensation by the patient or his or her physician. One expects that most work-related infections rapidly heal and therefore do not always lead to a compensation claim, unlike respiratory and osteomuscular diseases.

Doll \& Peto (50) attributed 2 to $8 \%$ of the cancer deaths among the general population (active + nonactive persons) in the United States to occupations. Our estimation ( 6 of 50 neoplastic diseases) is higher since it is based on occupationally active persons. In Belgium, the majority of occupational cancers is not reported to the health and safety inspectorate or the compensation board. Over the eight-year period 1979-1986, the average annual number of cancer cases compensated by the Belgian Work Compensation Fund was only 48, compared with an annual number of approximately 4000 compensated occupational diseases (51). In 1983, of 12869 cancer cases registered for men by the Belgian Cancer Registry, $68(0.5 \%)$ were submitted to the Belgian Work Compensation Fund (51). Although hearing loss and skin lesions are frequent occupational health problems, very few patients with these complaints were found in the study. These patients would not normally be hospitalized.

In summary, over $25 \%$ of hospital inpatients in general internal medicine who have held employment have or have had work-related pathologies. This finding justifies a detailed occupational record for all employed patients admitted to any other medical ward (eg, pneumology, oncology, hematology, nephrology, gastroenterology, neurology). Although respiratory and orthopedic conditions are more frequently related to occupation than other diseases, any organ can be the target of an occupational hazard. Medical criteria alone are not sufficient to identify the patients whose illness may be work-related and for whom a detailed work history should be obtained by an expert physician. Accurate and systematic work histories must be obtained for each patient. Several authors (52-57) have stressed the importance of training internists (and general practitioners) to consider work-related causes in their diagnoses. However, in, view of the complexity and rapidly changing pattern of occupational health risks, it is unlikely that internists will ever be able to assess in detail the present and past occupational history of their patients. Industrial position titles (as listed in table 1) do not frequently permit the assessment of potential occupational hazards. Furthermore current employment is not always representative of usual occupational exposure conditions (58). A detailed inquiry about each patient's past and present activities is required to pinpoint exposure to any occupational health risks. This task can only be performed by an occupational physician because it not only involves the description of current and previous occupational exposure conditions, but also the assessment of a possible link between the diagnosed pathology and the occupational activities.

It should also be stressed that correct, careful, and accurate work records are not only central for deciding whether a patient presents an occupational disease, they may also contribute to the identification of new occupational health risks. Indeed, this information constitutes an essential tool for the proper design of epidemiologic studies.

\section{References}

1. Sokas RK, Orellana L, Day SC. Using review of medical clinic charts to teach occupational health. J Med Educ 1988;63:125-30.

2. Cullen MR, Cherniack MG. Spectrum of occupational disease in an academic hospital-based referral center in Connecticut from 1979 to 1987. Arch Intern Med 1989; 149:1621-6.

3. Rosenstock L, Logerfo J, Meyer NJ, et al. Development and validation of a self-administered occupational health history questionnaire. J Occup Med 1984;26:50-4.

4. International Labour Office (ILO). International standard classification of occupations 1968. Geneva: ILO, 1968.

5. World Health Organization (WHO). International classification of diseases (1975 revision). Geneva: WHO, 1977.

6. Parkes WR. Occupational lung disorders. 2nd edition. London: Butterworths, 1982.

7. Leigh J, Wiles AN, Glick M. Total population study of factors affecting chronic bronchitis prevalence in the coal mining industry of New South Wales, Australia. $\mathrm{Br} \mathrm{J}$ Ind Med 1986;43:263-71.

8. Minette A. Apport épidémiologique à l'étiologie de la bronchite chronique des mineurs du charbon [Doctoral dissertation]. Louvain (Belgium): Catholic University of Louvain, 1976.

9. Gantz NM. Infectious agents. In: Levy BS, Wegman $\mathrm{DH}$, ed. Occupational health. Boston, Toronto: Little, Brown and Company, 1983:235-50.

10. Desoille $\mathbf{H}$, Scherrer J, Truhaut R. Precis de médecine du travail. Paris: Masson, 1975.

11. Dutkiewicz J, Jablonski L, Olenchock SA. Occupational biohazards: a review. Am J Ind Med 1988;14:605-23.

12. Pull JM, Wernsdorfer W, Lepes T. Malaria. In: Parmegiani L, ed. Encyclopaedia of occupational health and safety. 3rd edition. Geneva: International Labour Office, 1983.

13. Edling $\mathrm{C}$, Odkvist $\mathrm{L}$, Hellquist $\mathrm{H}$. Formaldehyde and the nasal mucosa. Br J Ind Med 1985;42:570-1.

14. Troup JDG. Causes, prediction and prevention of back pain at work. Scand J Work Environ Health 1984;10: 419-28.

15. Anderson JAD. Arthrosis and its relation to work. Scand J Work Environ Health 1984;10:429-33.

16. Walsh K, Varnes N, Osmond C, Styles R, Coggon D. Occupational causes of low-back pain. Scand J Work Environ Health 1989;15:54-9.

17. Aronow WS. Effect of cigarette smoking and of carbon monoxide on coronary heart disease. Chest 1976; 70:514-8.

18. Astrup R, Kjeldsen $\mathrm{K}$. Model studies linking carbon monoxide and/or nicotine to arteriosclerosis and cardiovascular disease. Prev Med 1979;8:295-302.

19. Cohen SJ, Deane M, Goldsmith JR. Carbon monoxide and survival from myocardial infarction. Arch Environ Health 1969;19:510. 
20. Kurppa K, Hietanen E, Klockars M, et al. Chemical exposures at work and cardiovascular morbidity: atherosclerosis, ischemic heart disease, hypertension, cardiomyopathy and arrhythmias. Scand j Work Environ Health 1984;10:381-8.

21. World Health Organization (WHO). Carbon monoxide. Geneva: WHO, 1979. (Environmental health criteria; no 13).

22. Zenz C. The epidemiology of carbon monoxide in cardiovascular disease in industrial environments: a review. Prev Med 1979;8:279-88.

23. Dømssing $M$, Skinhøj P. Occupational liver injury: review article. Int Arch Occup Environ Health 1985;56: $1-21$.

24. Franco G, Fonte R, Candura F. Hepatotoxicity of organic solvents. $\mathrm{Br}$ J Ind Med 1986;43:139.

25. Blair A. Cancer risks associated with agriculture: epidemiologic evidence. Basic Life Sci 1982;21:93-111.

26. Cantor KP. Farming and mortality from non Hodgkin's lymphoma: a case-control study. Int J Cancer 1982;29: 239-47.

27. Hardell L, Erikson M, Lenner P, Lundgren E. Malignant lymphoma and exposure to chemicals, especially organic solvents, chlorophenols and phenoxyacids: a case-control study. Br J Cancer 1981;43:169-76.

28. Hoar SK, Blair A, Holmes FF, et al. Agricultural herbicide use and risk of lymphoma and soft tissue sarcoma. JAMA 1986;256:1141-7.

29. Hoar Zahm S, Blair A, Holmes FF, Boysen CD, Robe RJ. A case-referent study of soft tissue sarcoma and Hodgkin's disease: farming and insecticide use. Scand J Work Environ Health 1988;14:224-30.

30. Pearce NE, Sheppard A, Smith AH, Teague CA. Non Hodgkin's lymphoma and farming: an expanded casecontrol study. Int J Cancer 1987;39:155-61.

31. Saftlas AF, Blair A, Cantor KP, et al. Cancer and other causes of death among Wisconsin farmers. Am J Ind Med 1987;11:119-29.

32. Wiklund $\mathbf{K}$, Holm LE. Trends in cancer risks among swedish agricultural workers. J Natl Cancer Inst 1986; 77:657-64.

33. Ameille T, Le Tinier JY, Reigneau O, et al. Exposition professionnelle à l'inhalation de paraffine et pathologie respiratoire. Arch Mal Prof Med Trav Secur Soc 1984; 45:264-5.

34. Perrone $\mathbf{H}$, Passero MA. Hydrocarbon aerosol pneumonitis in an adult. Arch Intern Med 1983;143:1607-8.

35. Woo O, Healey KM, Sheppard D, et al. Chest pain and hypoxemia from inhalation of a trichioroethane product. J Toxicol Clin Toxicol 1984;25:333.

36. Bollinelli R, Rouch Y, Refregier M, Doyon B. Facteurs industriels dans l'etiologie des maladies respiratoires obstructives: conséquences pour la prévention. Rev Fr Mal Respir 1983;11:383-96.

37. Pham QT, Benis AM, Mur JM, Sadoul P, Haluszka J. Follow-up study of construction workers with obstructive lung disease. Scand J Respir Dis 1977;58:215-28.

38. Baker EL, Fine LJ. Solvent neurotoxicity: the current evidence. J Occup Med 1986;28:126-9.

39. World Health Organization (WHO), Nordic Council of Ministers. Chronic effects of organic solvents on the central nervous system and diagnostic criteria. Copenha- gen, Oslo: WHO and the Nordic Council of Ministers, 1985.

40. Cartwright R. Occupational bladder cancer and cigarette smoking in West Yorkshire. Scand J Work Environ Health 1982;8(suppl 1):79-82.

41. Olsen JH, Jensen OM. Occupation and risk of cancer in Denmark: an analysis of 93810 cancer cases, 19701979. Scand J Work Environ Health 1987;13(suppl 1): $91 \mathrm{p}$.

42. Schoenberg JB, Stemhagen A, Mogielnicki AP, Altman $\mathrm{R}$, Abe T. Occupational exposures in white males. J Natl Cancer Inst 1984;72:973-81.

43. Snook SH. Back and other musculoskeletal disorders. In: Levy BS, Wegman DH, ed. Occupational health. Boston, Toronto: Little, Brown and Company, 1983: 341-56.

44. Bernard SY, Cartwright RA, Darwin C, et al. Hodgkin's disease: case-control epidemiological study in Yorkshire. Br J Cancer 1987;55:85-90.

45. Goldstein BD. Hematotoxicity in humans. J Toxicol Environ Health 1977;2(suppl 2):69-105.

46. Grossenbacher J, Lob M. Etude longitudinale des effets à long terme d'une exposition professionnelle au benzene. Schweiz Med Wochenschr 1982;112:1858-9.

47. Van Raalte HGS, Grasso P. Hematological, myelotoxic, clastogenic, carcinogenic and leukemogenic effects of benzene. Regul Toxicol Pharmacol 1982;2:153-76.

48. Kristensen TS. Cardiovascular diseases and the work environment: a critical review of the epidemiologic literature on chemical factors. Scand J Work Environ Wealth 1989;15:245-64.

49. Fonds des Maladies Professionnelles. Rapport annuel, exercice 1987, Brussels: Fonds des Maladies Professionnelles, 1987.

50. Doll P, Peto R. The causes of cancer: quantitative estimates of avoidable risks of cancer in the United States today. J Natl Cancer Inst 1981;66:1191-308.

51. Caroyer JM, Strauss P. Les cancers professionnels. Semper 1987; 10:32.

52. American College of Physicians. The role of the internist in occupational medicine: a position paper. Am J Ind Med 1985;8:95-9.

53. Cullen MR. Occupational medicine, a new focus for general internal medicine. Arch Intern Med 1985;145: $511-5$.

54. Dickinson KG. Occupational health and the general practitioner. Practitioner 1985;229:519-23.

55. Fischbein A. New dimensions in occupational medicine. Mt Sinai J Med 1985;52:478-9.

56. Sandler HM. Underdiagnosis of occupational illnesses [Letter to the editor]. New Engl J Med 1980;303:644.

57. Marcus RL, Lee WR. Information on occupational medicine for trainee general practitioners. J Soc Occup Med 1980;30:24-6.

58. Illis WR, Swanson GM, Satariano ER, Schwartz AG. Summary measures of occupational history: a comparison of latest occupation and industry with usual occupation and industry. Am J Public Health 1987;77: 1532-4.

Received for publication: 1 February 1991 